\title{
Peace and Conflict Studies
}

Volume 16

Number 2 Special Issue

Article 2

$12-2009$

\section{Military Modernization and Peaceful Rising: A Harmonious Transition of the PLA into the Future}

Xiaobing Li

University of Central Oklahoma, bli@uco.edu

Follow this and additional works at: https://nsuworks.nova.edu/pcs

Part of the Peace and Conflict Studies Commons

\section{Recommended Citation}

Li, Xiaobing (2009) "Military Modernization and Peaceful Rising: A Harmonious Transition of the PLA into the Future," Peace and Conflict Studies: Vol. 16 : No. 2 , Article 2.

DOI: $10.46743 / 1082-7307 / 2009.1105$

Available at: https://nsuworks.nova.edu/pcs/vol16/iss2/2

This Article is brought to you for free and open access by the Peace \& Conflict Studies at NSUWorks. It has been accepted for inclusion in Peace and Conflict Studies by an authorized editor of NSUWorks. For more information, please contact nsuworks@nova.edu.

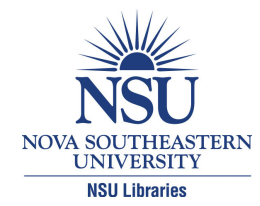




\section{Military Modernization and Peaceful Rising: A Harmonious Transition of the PLA into the Future \\ Abstract}

This article seeks to elucidate the recent changes to the Chinese military by examining the new characteristics of the People's Liberation Army (PLA) and its newly adopted approaches for modernization between 2003 and 2008. It includes diachronic discussions to explore various social and political factors for the changes, domestic and international constraints on the implementation of military modernization, and the outcomes of these endeavors. The main findings indicate that the Chinese military has changed its main feature as two important transitions have emerged: first, the PLA has been transformed from a manpower intensive army to a technology oriented force; and second, from a national security army to an internationally operated force. Consequently, the high command begins to consider the PLA as a part of the global military cooperation.

Keywords: Chinese Communist Party (CCP), Chinese military, Mao Zedong, military modernization, People's Liberation Army (PLA)

\section{Author Bio(s)}

Xiaobing Li, professor, chair of the Department of History and Geography, and director of Western Pacific Institute at the University of Central Oklahoma, is the author, editor, and co-author of the books: Civil Liberties in China (2010), Voices from the Vietnam War (2009), New Historiography in the Contemporary West (2008), A History of the Modern Chinese Army (2007), Taiwan in the 21st Century (2006), Voices from the Korean War (2005), Chinese Immigrants in the U.S. (2004), Mao's General Remember Korea (2002), Social Transition in China (2001), China and the United States (2000), Asia's Crisis and New Paradigm (1999), and Re-Interpreting U.S.-China-Taiwan Relations (1998). He is the editor of American Review of China Studies and the Journal of Western Pacific. Email: bli@uco.edu 


\title{
Military Modernization and Peaceful Rising:
}

\section{A Harmonious Transition of the PLA into the Future}

\author{
Xiaobing Li
}

\begin{abstract}
This article seeks to elucidate the recent changes to the Chinese military by examining the new characteristics of the People's Liberation Army (PLA) and its newly adopted approaches for modernization between 2003 and 2008. It includes diachronic discussions to explore various social and political factors for the changes, domestic and international constraints on the implementation of military modernization, and the outcomes of these endeavors. The main findings indicate that the Chinese military has changed its main feature as two important transitions have emerged: first, the PLA has been transformed from a manpower intensive army to a technology oriented force; and second, from a national security army to an internationally operated force. Consequently, the high command begins to consider the PLA as a part of the global military cooperation.
\end{abstract}

\section{Introduction}

In the recent years, the Chinese military has experienced a wave of growth and improvement in terms of organization, technology, and combat training. The on-going changes in the People's Liberation Army (PLA, as China's army, air, naval, and strategic missile services are collectively known) and the inevitable implication in Asia-Pacific security have attracted great academic attention in the West, especially in the United States. Mark A. Ryan, David M. Finkelstein, and Admiral Michael A. McDevitt suggest that as a growing field, research literature on Chinese military modernization began to "take off" in the 1990s (Ryan, Finkelstein, and McDevitt, 2003, p.3). Among the recent insightful assessment on the matter, David Shambaugh, Andrew Scobell, and several other Chinese military experts offer objective surveys and comprehensive interpretations through analyzing PLA strategy, doctrine, command and control, structure of forces, and security concerns (Shambaugh, 2002; Scobell, 2003).

This article seeks to elucidate the recent changes to the Chinese military by examining the PLA's new characteristics and different approaches from 2003 to 2008. Although it is a military survey, it includes diachronic discussions to explore the social and political reasons for change, domestic and international constraints on the implementation of military modernization, and the outcomes of these efforts. Based upon the Chinese sources, up-to-date literature both in Chinese and English, and interviews with PLA officers, this work intends to answer these questions by analyzing the recent transition in the Chinese military as a political and social institution. The article looks into the relatively neglected inner life cycle of the Chinese armed forces, which has defined the PLA's characteristics and changed it in many different ways. The stories of the rank and file

$\underline{\text { Peace and Conflict Studies }}$ • Volume 16, Number 2 
provide unique insights into those who have shaped the military and made unprecedented changes over the past decade. They put individual soldiers and officers in the context of Chinese society, culture, and tradition and view them through their personal experience and professional career.

As a newly modernized army, the PLA acts according to its own consistent inner logic in its military affairs. The main findings here indicate that the Chinese military has changed the main characteristic as the results of its two important transitions. First, the PLA has transferred from a manpower intensive army to a technology oriented force; and, second, from a national security army to an internationally operated force. The high command of the Chinese military begins to consider the PLA as part of the world military cooperation such as fighting the global terrorists, combating the pirates along the African coasts, keeping peace in the Middle East, and preparing a possible nuclear crisis in the Korean Peninsula. A PLA perspective offers a better understanding of Chinese strategic issues and operational behaviors. The article also identifies some general patterns of the new generation of the high command that faces new challenge.

\section{“China Threat” vs. Peaceful Rising}

Few areas in Chinese history pose more difficulties than the study of military history, due to a lack of readily available sources for Western researchers. The studies in this article are supported by primary and secondary sources made available in recent years. Since the late 1980s, significant progress towards the study of Chinese military history has occurred. The flowering of the "reform and opening" era in China resulted in a more flexible political and academic environment compared to the time of Mao Zedong, the first generation of the Chinese Communist Party (CCP) leadership and the founder of the People's Republic of China (PRC), leading to a relaxation of the extremely rigid criteria for releasing party and military documents. Consequently, some fresh and meaningful historical materials, including papers of the former leaders, party and government documents and local archives, are now available to historians. Certainly, the Chinese government still has a long way to go before "free academic inquiry" becomes a reality, but the value of the opening of documentary materials for the study of military history cannot be underestimated.

Some of the noted experts in the field have employed the newly available Chinese sources, such as David Graff, Robin Higham, Hans van de Ven, and others military experts who addressed issues in PLA technology, budget and finance, defense industries and operations (Graff and Higham (eds.), 2002; Hans van de Ven, 2000). The combined efforts of these scholars laid solid groundwork for a better understanding of the Chinese military. Now the public interests and academic debates focus on the following questions: Why did Chinese military increase its defense budget by double digit every year? What kind changes have taken places in the PLA? How is the Chinese government balancing between its military modernization and peaceful rising promise? What does it mean to the United States and the international community?

The current research available both in the United States and in the West have engaged in academic debate on the "China threat". dominating attention and dividing scholars. U.S. 
Military historians and experts are attempting to determine if China threats America and security in the Pacific region and at what level the threat exists in the twenty-first century. According to the China threat researchers, their main argument is based on the assumption that China's dramatic economic development will inevitably result in the "strengthening of its military power and its desire for expansion” (Karmel, 2000, pp. 3-5, p. 8; Babbin and Timperlake, 2006). Proponents of the interpretations argue that no country that rose to power in modern world history did so in a peaceful manner, citing examples such as Great Britain in the eighteenth century, Germany toward the end of the nineteenth century, Japan during the first half of the twentieth century and the Soviet Union after the end of World War II (WWII) (Chang, 2001; Getz, 2000; Bernstein and Munro, 1997). Conversely, they assert, any country that insists on the maintenance of peace will find it hard, if not impossible, to become a real power (Bernstein and Munro, 1997; Kristof and Wudunn, 1994). Furthermore, they argue, the lack of political democratization in China and the distinct possibility of a war between the mainland and Taiwan make the future of China uncertain, unpredictable and, therefore, extremely menacing (Kristof and Wudunn, 1994). Others may disagree and offer an entirely opposite view. Nevertheless, both sides of the argument pay their attention to the links between the military modernization and political democratization.

Like the China-threat debate, discussions over the topics such as the impending collapse, Chinese exceptionalism, China replacing Russia, or China replacing Japan also center the issue of China's military modernization. Some of the American and Western military experts, however, have major restraints on their researches as they had very limited access to the seemingly impregnable Communist sources. Their conclusions have to draw from the publications in the West. Some have to depend on materials in English or other western languages because of the linguistic difficulties and cultural barriers. Some researchers still follow Cold War approach with ideological definitions viewing the PLA as a party-army or the party's tool, and merely as a political institution. Others employ an American-centered methodology, over-emphasizing diplomatic efforts and international relations and viewing the PLA as an insignificant, passive spectator or lesser adjunct in world politics. Apparently, a broader interpretation is needed in order to render an objective study of the Chinese military.

In China, scholars are working on their research on the Chinese military through a social approach. Paying more attention to the links between military, politics, and society, recent research by military experts in China focuses on the soldier's efforts to define his place within a socialist society. Moral issues, family values, individual concerns, a bureaucratic system, and educational factors are emphasized through the academic discussions during the reforming movement led by Deng Xiaoping, the second generation of the CCP leadership. Among the recent publications, the persistence of a military culture counter-posed to an official culture that promotes bureaucratic control and civil-military integration (He, 2001; Ge, 2000; Tan, 1992; Hu, 1992). For some political reasons, however, Chinese scholars still have a long way to go before objective, truthful, and scientific researches on the history of Chinese military can be published in their home country. 
The Chinese intention can be best understood in the historical terms and in a context of their own time. Four elements were underlying their motivation and intent: a global political context formed to a large extent by the United States and the Soviet Union; domestic political and economic developments; an overall foreign policy of the PRC; and means and sources available at that moment. Though our analysis in this article, one can see that the Chinese leaders pursued their political goal of a full acceptance in the world community with limited alternatives.

\section{Changing Characteristics}

After taking over the office, Hu Jintao, as the fourth generation of the CCP leadership, stated that the PLA should resort to different warfighting means in future conflicts, including a high-tech approach to circumvent enemy strengths and confront it in ways it would not be able to match in kind. Thus, for at least next ten years by 2012, China will "not be intimidated by a military superpower". and China's foreign policy will "not be constrained by its military weakness" (Hu, 2000, p.1). According to Hu Jintao and his new high command, the PLA should make a "leap-over" transition from an army with mechanical and semi-mechanical equipment to an army equipped with digital facilities. General Zhang Zhen, Vice Chairman of the CCP's Central Military Commission (CMC), anchored in the "leap-over" idea when he spoke at a joint warfare seminar. Zhang believed that the next war will take place in an urban area, or even in one of the major cities, where China centers its technology (Yu, 1998, p.2). The new high command gave its priority to the new technological development in the navy, air force, and strategic forces, "in order to strengthen the capabilities for winning both command of the sea and command of the air, and conducting strategic counter-strikes” (Information Bureau, 2005, p.645).

To deal with the problems left behind by Jiang Zemin, the third generation of the CCP leadership, Hu Jintao had made certain important changes in the military regulations. In December 2003, the new "Regulations on the Political Work of the PLA" was revised and promulgated. It maintains that political work is the fundamental guarantee of the Party's absolute leadership over the armed forces and assurance for its accomplishment of the missions (Information Bureau, 2005, p.654). In February 2004, the CMC released the "Provisions on Strengthening the Education and Management of High- and MiddleRanking Officers of the PLA" which established and refined the systems for officers at the regimental level and above to do self-study and review, to receive thematic education. On March 14, the new leaders revised the PRC Constitution at the Second Plenary Session of the Tenth National People's Congress. In April, the CMC promulgated the "Regulations on the Work of the CCP Armed Force Committees." The new regulations further defined the duties and responsibilities of the Party committees and further improved the decisionmaking procedures of the PLA (Li, 2007, pp.292-293).

Then, Hu Jintao remove some of the old-guard generals and improved the chain of command by announcing a reduction of 200,000 troops by 2006 and rebalance the ratio between officers and men. By streamlining structure, he reduced the number of officers in deputy positions, filled officers' posts with NCOs (Non-commissioned Officers), and 
adopted a system of civilian employees. By 2006, the PLA reduced 15 percent of its staff officers at the group army level and above (Information Bureau, 2005, p.644). The high turnover rate of the PLA elites reflects an effective institutional mechanism by which the top civilian leaders prevent the emergence of military strongman and possible stagnation of the military establishment.

The PLA also set up the new or lower maximum age limits for peacetime active service. According to the 2004 White Papers of China's National Defense, active officers who have reached 40 years of age at the battalion command level, 45 at the regimental level, 50 at the division, and 55 at the army, should be discharged from active service in the combat troops (Information Bureau, 2005). The retirement ages for officers in the noncombat troops are 40 at the battalion command level, 50 at the regiment, 55 at the division, and 60 at the army (Information Bureau, 2005, pp.668-670). After Hu's streamlining, the average age of the PLA top officers has significantly decreased after the large-scale military leadership turnover (Li, 2001, p.58). In 2008, Hu approved regulations on the duty of PLA soldier committees. The PLA's soldier committee is a self-governing mass organization, responsible for carrying out grass-root activities, promoting military democracy, and assisting party branch in each company. The new regulations are aimed to ensure harmony and purity among soldiers' inner relationships and promote the army's scientific development (PLA Daily, June 6, 2008, p.6).

With the completion of reducing 200,000 ground forces in 2004-2006, the PLA has a significant increase in its navy, air force, and strategic forces. Of the total of 2.4 million troops, the PLA Navy and Air Force have raised 3.8 percent, and the Second Artillery Corps (China's strategic and tactical missile force) has increased 4.2 percent (Information Bureau, 2006, pp.17-18). David J. Kay at the U.S. Army's Institute of Land Warfare believes that the "reduction of the PLA end-strength is intended to free up more resources for modernization and professionalization of the force, and is wholly consistent with China's improved security environment and growing national interest” (Kay, 2008, p.4). He continues that "With regard to internal threats, China mainly relies on the 660,000strong People's Armed Police for such contingencies as the recent unrest in Tibet” (Kay, 2008, p.4). Meanwhile, a large number of college graduates, master and Ph.D. degree holders, and returning students from overseas have been recruited among the services ( $\mathrm{Li}$, 2007, pp.2-3, pp.293-294).

From 2006-2008, the Party Center has sped up legal reform to achieve their goal of making the rule of law "the principle tool to govern the country." New legislation has been adopted on a wide range of issues such as soldier's duties and rights, the military administration, access to public records, and the handling of emergencies. These reforms have had a strong impact on the military system. Because of a societal environment increasingly supportive of legal reform, more and more officers and soldiers have become aware and conscious of their rights as citizen soldiers. The concept of using legal means to protect these rights has made significant progress. This development has had a very important impact on the Chinese military modernization.

In the past years, the military legislative system has been improved step by step, and some achievements have been made in military legislation. Two interesting, but somewhat contradictory trends can be observed: first, the separation of the army from the Party; and 
second, keeping the military to reinforce the new rule of law. The former restrains the Party's power while the latter presses the government to use its power to pursue justice. Both trends, however, appear to serve the purpose of promoting constitutional rights over the state itself. According to the 2008 White Papers of China's National Defense, by October 2008, the National People's Congress and its Standing Committee had made 15 laws and law-related decisions concerning national defense and armed forces building. The PRC's State Council and CCP's CMC had jointly formulated 94 military administrative regulations. The CMC had formulated 215 military regulations. In the meantime, the general headquarters and departments, Navy, Air Force, Second Artillery Force, military area commands, had enacted more than 3,000 military rules and regulations (Information Bureau, 2008, pp.5-7). The PLA began to govern the forces in accordance with the law, and improves the mechanism for making decisions and providing guidance in accordance with the law in an effort to institutionalize and regularize military, political, logistical, and equipment work.

\section{New Personality, New Technology}

After the $17^{\text {th }}$ CCP Congress, the high command continues to promote the revolution of military affairs (RMA) with Chinese characteristics. Obviously, in the past year, the modernization efforts have focused on the task of mechanization while keeping pace with the building of an information-age force. The PLA reaffirms its modernization with an emphasis of special needs to transform its semi-mechanical equipment to an army equipped with modern technology and digital facilities - an information-age force. As General Xiong Guangkai, deputy chief of the PLA General Staff, explained that the PLA was still at the state of "semi-mechanization" (Xiong, 2003, p.4). In other words, the task of PLA mechanization had not yet been completed. Xiong believed that the mechanization efforts would try to keep pace with the building of an information-age force, which in turn would be boosted by mechanization. "We shall promote both processes to eventually succeed in fulfilling the dual tasks of mechanization and informationization” (Xiong, 2003, pp. 182183). Xiong said. "No distinct line should be drawn between the two and we should never depart from our country's actual situation and the realities of our armed forces” (Xiong, 2003, pp.182-183). To reach its goal, the PLA has to reform virtually all aspects of its gigantic institution in order to prepare for the "new era of information warfare.” On March 21, 2008, Hu Jintao visited the Academy of Military Sciences, China’s primary military think tank, on its $50^{\text {th }}$ anniversary. He showed great interest in a demonstration at the academy's lab, which is known as the Research and Experimental Center for Joint War Action (Hu, 2008, p.1). The top leader praised the academy's comprehensive method of studying major practical issues. He urged the academy to drive forward the innovation of military theory and develop military sciences, so as to meet the requirements of the $17^{\text {th }}$ CCP National Congress and new conditions.

In the past years, with an annual growth rate of 7-8 percent, the Chinese government was able to double its defense budget, purchasing new weaponry and importing high tech from Russia and the West to narrow down the technology gap between the PLA and the major Western armed forces. With an eclectic attitude toward the Western technology, the 
Chinese military made changes in those imported weapon systems and tried to fit those into whatever they needed, making the best use of imported technology and letting all things serve their purpose. Their ways such as "third party purchase”, "copy and learn" and "leaping over" can be defined as the problem-solving and unique characteristics of Chinese military modernization for many years to come. Thus, the Chinese military reform is an outcome of both social and economic changes that are not only interrelated, but also interdependent. China's foremost task in its drive toward military modernizations should be the successful completion of market economy reforms. To build a modern army, it must build an industrial and sustained economy.

In a keynote speech at the $17^{\text {th }}$ National Congress of the CCP in October 2007, Hu Jintao said, "China is to speed up the pace of modernizing its armed forces in the next five years and more, for self-defense and maintaining world peace” (Hu, 2007, p.12-13). The General Secretary of the CCP Central Committee and the Chairman of the CMC promised the party that "We must implement the military strategy for the new period, accelerate the revolution in military affairs with Chinese characteristics, ensure military preparedness, and enhance the military's capability to respond to various security threats and accomplish diverse military tasks” (Hu, 2007, p.15). To attain the strategic objective of building computerized armed forces and winning IT-based warfare, Hu said China would accelerate the composite development of mechanization and computerization, carry out military training under IT-based conditions, intensify their efforts to train a new type of high-caliber military personnel in large numbers and change the mode of generating combat capabilities. China will establish sound systems of weapons and equipment research and manufacturing, military personnel training and logistics that integrate military with civilian purposes and combine military efforts with civilian support, build the armed forces through diligence and thrift, and blaze a path of development with Chinese characteristics featuring military and civilian integration (Hu, 2007, pp.18-19).

After the CCP's $17^{\text {th }}$ National Congress, the PLA is one of extreme intricacy and one of great consequence. The year after the $17^{\text {th }}$ Congress is more effectual than ever before in terms of military modernization, civil-military integration, and international cooperation in a new domestic and international environment. Among the services, the Navy has a lion share of the annual defense budget in the recent years. There are more than 30 new submarines became commissioned into the Navy, which is also developing four indigenous classes of submarines. It has focused on the anti-ship cruise missiles (ASCMs) system, including formidable Sizzler and Sunburn missiles. Some of these ballistic missiles will be able to carry nuclear warhead, and provide the nuclear deterrence against any offshore threat or naval engagement (Goldstein, 2008, p.4; Getz, 2008, p.1). The Navy began the construction of the large Sanya naval base on Hainan Island. This southward base in the middle of the South China Sea and protecting the Gulf of Tonkin provides the PLA Navy a powerful position to deploy its gunships and submarines into deep waters (Harding, 2008, p.2).

The other area that continues to improve is in the Second Artillery Corps, responsible for establishing China's "minimal nuclear deterrent." According to the U.S. Secretary of Defense's 2008 Annual Report to Congress, the Second Artillery Corps has more than 300 nuclear warheads with 20 inter-continental ballistic missiles (ICBMs) and one ballistic 
missile submarine (SSBN) (U.S. Department of Defense, 2008, p.9). The Second Artillery Corps is preparing to field a new solid-fuel and road-mobile Dong Feng 31A ICBM system in order to increase the survivability of its nuclear deterrent. The new ICBNs will be combat ready faster than the liquid-fueled missile, and more quickly launched and easier to hide. Moreover, the Second Artillery Corps has more than 1,300 Dong Feng 11 and 15 short-range ballistic missiles along the coastal areas. It is expected to continue to expand its ICBM capabilities and improve upon its land attack cruise missile and anti-ship missile arsenals (Minnick, 2008, p.2). It is interesting to notice that China states for the time in its 2008 White Papers of China's National Defense that "China holds that all nuclear-weapon state should make an unequivocal commitment to the thorough destruction of nuclear weapons, undertake to stop research into and development of new types of nuclear weapons, and reduce the role of nuclear weapons in their national security policy" (Information Bureau, 2008, pp.12-13).

The PLA has worked on other programs such as space programs, cyber warfare projects, and information and electronic warfare operations. Its successful test of the antisatellite weapons (ASATs) can be used against enemy satellites. ASATs can also be used to increase the survivability of the Chinese nuclear deterrent by knocking out enemy instruments to detect and destroy Chinese delivery system (Kay, 2008, p.5). On September 27, 2008, the spacewalk performed by Chinese aeronaut marked another breakthrough in China's space program. When congratulating the trio taikonaults, Hu encouraged the Chinese aerospace scientists and experts to continue their efforts for a complete success (Hu, 2008, p.1). But he stressed the country early this year that China still faced a large gap with the world's advanced levels in the science and technology development. In a speech at the joint inaugural ceremony of both of the $14^{\text {th }}$ Congress of the Chinese Academy of Sciences (CAS) and the Ninth Congress of the Chinese Academy of Engineering (CAE) on June 23, 2008, Hu admitted that there is "still a large gap" with the world's most advanced (Hu, 2008, p.2). U.S. Department of Defense's 2008 Annual Report to Congress also concludes that "The U.S. Intelligence Community estimates China will take until the end of this decade or longer to produce a modern force capable of defeating a moderate-size adversary. China will not be able to project and sustain small military units far beyond China before 2015, and will not be able to project and sustain large force in combat operations far from China until well into the following decade” (U.S. Department of Defense, 2008, p.12).

\section{New Image with Legacy}

The PLA has played a positive role in emergency rescue and disaster relief operations. In the past two years, the PLA have dispatched a total of 600,000 troops, employed 630,000 vehicles or machines of various types, flown over 6,500 sorties, participated in over 130 disaster relief operations in cases of floods, earthquakes, snowstorms, typhoons, and fires. In January 2008, large areas of southern China were stricken by a savage spell of freeing weather, sleet and snowstorms. The PLA sent 224,000 troops and 1 million reservists to undertake urgent tasks. On May 12, an earthquake rocked 
Wenchuan County, Sichuan Province. In response, the PLA deployed 146,000 troops, mobilized 75,000 reservists, flew over 4,700 sorties and employed 533,000 vehicles in the relief effort. They rescued 3,338 survivors, evacuated 1.4 million local residents, and transported 1.6 million tons of relief materials. The PLA was tested by massive rescue, disaster release, and joint forces expeditionary capabilities (Information Bureau, 2008, p.14).

During the 2008 Beijing Olympic Games, the main responsibilities of the PLA were to ensure the air security of venues in and outside Beijing; take part in the handling of terrorist incidents such as NBC (nuclear, biological, and chemical) terrorist attacks; provide intelligence support; organize emergency rescue, medical aid; and strengthen border administration and control during the Olympics. The PLA contributed 46,000 troops, 98 fixed-wing aircraft, 60 helicopters, 63 warships, and some ground-to-air missiles and radar, and engineering support equipment. The PAPF contributed 85,000 troops to Olympic security work and handled 300 incidents which might have endangered guarded targets.

The PLA has created a new situation in military diplomacy which is practical and dynamic. China has established military ties with over 150 countries, and has military attach offices in 109 countries. A total of 98 countries have military attach offices in China. In the past two years, senior PLA delegations have visited more than 40 countries, and defense ministers and chiefs of the general staff from more than 60 countries have visited China. Practical cooperation between the military forces of China and several neighboring countries, including Russia, has continued to develop in depth. In recent years, China has intensified bilateral and multilateral strategic consultation and dialogues with countries concerned in security and defense fields which contributed to better mutual trust and mutual exchange and cooperation. Beijing pursues a foreign policy of building a goodneighbor relationship and partnership with its neighbors, trying to create an amicable, secure, and prosperous neighborhood in the Asia-Pacific region. The PLA has consistently supported and actively participated in the peacekeeping operations that are consistent with the spirit of the UN Charter. Since its first dispatch of military observers to the UN peacekeeping operations in 1990, the PLA has sent 11,063 military personnel to participate in 18 UN peacekeeping operations. As of the end of November 2008, China had 1,949 military peacekeeping personnel serving in nine UN mission areas and the UN Department of Peacekeeping Operations. Since 2000, China has sent 1,379 peacekeeping policemen to seven mission areas (Information Bureau, 2008, pp.17-18).

And $\mathrm{Hu}$ has to face tremendous difficulties in China's economic and political reforms in the midst of continuous social transition. Even though $\mathrm{Hu}$ and Jiang had many disputes over specific issues, they have reached a consensus on the key objective: China's economic growth and social stability. In the first decade of the new century, however, Chinese analysts worry about the country's macro-economic instability and potential problems. At a recent conference, the strategic researchers pointed out that macro-economic instability has successfully been contained through the government control of the right policy levels. The current economic and social liberalization, however, drastically undermined the authority's role and old-style administrative edicts. In the near future, the new problems in Chinese economy may not be solved in the old way through the failing system and decentralized control. 
The new leadership in Beijing will not abandon the deliberate approach its previous generation had employed with success for the military reforms. Yet this importation/adoption approach may keep the PLA forever behind the Western armed forces, and make its modernization totally dependent on economic success. Any economic recession will slow down or stop China's military modernization. Chinese analysts worry about the country's macro-economy instability and some problems such as unemployment, limited natural resources, energy cost and price hikes, a weak financial system, state-owned enterprises, and a decline of foreign investment. Even though these serious challenges will not occur simultaneously, occurrence of some of the problems is certain and will cause serious troubles in the country's economy. Some Western analysts concern that these problems may lead to a more aggressive foreign policy or even military expansionism.

To keep the military under control, a continuing coalition between the PLA and the CCP is necessary for Beijing. At the National People's Congress in 2005, Hu Jintao's vision for "harmony and innovation" became government policy for China's further development. To achieve a harmonious China in a new time, it is important to build on its long and rich traditions and preserve them in innovative ways. The PLA needs to follow the fundamental principle and system of absolute Party leadership over the armed forces. In other words, the PLA should support the Hu administration by showing their loyalty to the Party Center. The ranks and files should value the social harmony, share ideas, and live with them as social norms. The high command needs to contribute to various forms of rationale to promote social harmony. In this socio-economic climate, the concept of harmony is becoming increasingly valuable and pertinent to the Chinese society as well as the rest of the world.

The PLA still belongs to the Party since the latter controls the resources and personnel management for military budget and professional career under the current leadership. The Party Center can channel the military elite interests and individual consciousness, prejudice, and conflict of the rank and file through the existing strong political institution. Since the state has adapted well to economic and social changes and effectively responded to the rising demands and expectations with the PLA, its political institutions may be able to manage some of the discontent or different opinion of the PLA in the near future (Shambaugh, 2005, p.11). These activities are still within the boundaries of the Party Center's preference and control. In the meantime, the PLA should also provide new military capabilities for the policy since there are serious disharmonious factors and unstable elements in China and in the world. As we know, in the past two decades, disparity in wealth, unsettled social political infrastructure, and international conflicts have resulted in a new set of uncertainties and challenges for China's sustained development.

Thus, social problems and domestic difficulties will slow China's ascendancy in the military reform and global politics to some extent. To build a modern army, it must build a confident and democratic society, and this will not be possible without drastically improving its political system. The task will be both costly and complex to execute. Few countries in history have successfully achieved such tumultuous transformation under uncertain circumstances China is currently facing. Unlike Japan's Meiji Restoration in the mid-nineteenth century, China is being forced to undergo wholesale reforms to great extent led by the elite and citizens who have become much more knowledgeable about the world 
community and vocal for their wishes and desires. The new leadership can hardly afford any illusion that the Chinese public will allow them a leisurely reform drive. The Chinese people, like most global villagers today, demand instant satisfaction. To meet the public's growing, impatient expectations while maintaining the basic political structure acceptable to the old ideological leadership will require very creative politics.

Nevertheless, our historical overview shows the changing characteristics of the PLA in the recent years. The analysis includes three elements of the process by which the Chinese military moved from a peasant army to a professional one. The first facet includes human resources available for military revolution and reforms. Our stories about peasant soldiers help to better understand how their values, duties and concerns affected the military as an institution. The organization was firmly entrenched in Chinese tradition and society. The PLA was one of the few entities in the PRC that enjoyed some praise and recognition of the past. It takes time for a major transition and significant changes. The second element indicates the pressure on reform and their limits, including backward technology, poor living standard, lack of education and professional training, and authoritarian government within the society. The third is the way the military compromised for difficult changes while shaping both Chinese attitude and international view toward the PLA and China. The objective of this analysis process is to effectively present national interests, security concerns, perceived threats, and international conditions.

\section{U.S.-China Military Relations}

Now China stands as one of the most important states in the world. As a "responsible stakeholder”, China is being asked to contribute its support to strengthening the international order. As two of the most important members of the international community, the United States and China are both affected by some of the same threats - terrorism, the proliferation of weapons of mass destruction, the energy crisis and the financial crisis. The cooperation and coordinated action to effectively combat these problems will be mostly welcome. In the past year, there have been several positive developments in U.S.-China military relations. For example, on April 10, 2008, the U.S. and China installed an emergency hotline between the U.S. Department of Defense and the Chinese Ministry of National Defense (MND). This hotline was subsequently used for the first time shortly after the devastating May 12 earthquake relief efforts. Since then, U.S. military aircraft have flown in millions of dollars worth of supplies and the U.S. military has provided Chinese authorities with imagery from military satellites of areas affected by the earthquake. In preparation for the Beijing Olympics the U.S. government has provided Chinese authorities with security training, equipment, and personnel to help make the event incident-free (Kay, 2008, p.8). The two militaries have also formally launched military archive cooperation on information relating to U.S. military personnel missing in action around the period of the Korean War.

Despite these positive advancements, however, the overall picture of U.S.-China military cooperation is considerably bleak. According to the Department of Defense's 2008 Annual Report to Congress, "Much uncertainty surrounds China's future course, in 
particular in the area of its expanding military power and how that power might be used" (U.S. Department of Defense, 2008, p.1).

The lack of transparency in the Chinese military and national security apparatus is a major hindrance to more productive U.S.-China military/security relations. Where the United States annually releases various reports detailing its national security strategy and military procurements, China does no such thing. Instead, China regularly denies and obscures the intention and its annual defense budget. For the second year, China has sent its annual military expenditures to the United Nations Military Budget Transparency Mechanism in early September 2008. The 2007 report said defense spending rose 17.6 percent to $\$ 57.2$ billion. The report said China's defense budget accounted for 1.4 percent of its GDP and 7.2 percent of its overall budget last year (Minnick, 2008, p.2). Government-controlled media was quick to say that spending was "moderate" compare with the U.S. defense budget of $\$ 700$ billion. The 2008 U.S. Department of Defense report on China's military said Beijing significantly under-reported its defense expenditures, which could be between $\$ 97$ billion and \$139 billion (U.S. Department of Defense, 2008, p.11). The report says the published figures do not include "large categories of expenditure, such as expenses for strategic forces, foreign acquisitions, military-related research and development, and China’s paramilitary forces” (U.S. Department of Defense, 2008, p.14).

In addition to its lack of transparency, some of China's behavior toward the United States would give the impression that it is not interested in friendly relations. In August 2006, a powerful ground-based laser blinded a U.S. surveillance satellite. Shortly thereafter, in November 2007, China denied safe harbor in the midst of dangerous weather to two small U.S. Navy minesweepers, the USS Patriot and the USS Guardian. Later that month, in the Kitty Hawk Incident, China scuttled a long-planned port visit by an American aircraft carrier to Hong Kong, where the U.S. sailors aboard would disembark to meet their families, who had traveled halfway around the world (Kay, 2008, p.9). In January 2007 China launched an ASAT to destroy one of its obsolete weather satellites, littering space with debris that threatens all satellites and persons traveling in space. Also, according to Immigration and Customs Enforcement and Department of Defense, China is the greatest source of both cyber attacks and espionage on U.S. military and government targets. Kay agree with some U.S. officials that "Rather than building trust between the United States and China, the reckless actions of the Chinese government give a distinct impression that China views the United States as an enemy and is seeking every opportunity to exploit an advantage no matter the consequences" (Kay, 2008, p.10). Some of Chinese actions seem supporting this kind of the concerns, such as when a Chinese submarine surfaced near the USS Kitty Hawk in November 2006, increase not only misunderstanding between both sides, but also the likelihood of an accidental conflict. Also, with regard to military exchanges and site visits China is generally anxious to visit U.S. military sites and meet American personnel but is extremely cautious when it comes to U.S. entreaties to do the same.

On March 8, 2009, the U.S. Naval survey vessel Impeccable was confronted by five Chinese naval ships. The incident occurred about 75 miles off Hainan Island, south of the Chinese mainland. The Chinese ships surrounded and harassed the USS Impeccable, which conducted surveillance in an area Beijing claimed jurisdiction over but other countries 
consider international waters, according to the American account. The Chinese ships tried to block the ship and snag its cables with hooks. The Americans used a fire hose to spray water at the Chinese. The chief American intelligence officer called the "most serious" military incident with China since 2001. On March 12, when U.S. President Obama met China's foreign minister, Yang Jiechi, President Obama told the Chinese foreign minister that the two countries need to raise "the level and frequency" of military dialogue "in order to avoid future incidents" like the high seas confrontation (quoted in Baker, 2009, p.1). The president pledged to work closely with China on stabilizing the global economy and pressing North Korea to give up nuclear weapons (Baker, 2009, p.1).

China's continuous efforts in military modernization show that the standard image in the West concerning Chinese military reforms during the first decade of the twenty-first century as a period of aggressive and self-centered. Yet the new leadership in Beijing seeks a growing role on the global political stage while assuring the international community that China does not pursue a policy of military and political hegemony in a conventional sense. The world community may be willing to accept China as a counterbalance to the United States or Japan. However, while China is repositioning itself by creating new gravity and critical mass in the Asia-Pacific region, there are potential problems for its new demands and needs. A possible source of crisis may come from the highly sensitive and increasingly dangerous issue of Taiwan's independence. In a broader and historical perspective, China's Taiwan policy will be driven or directed not necessarily by the communist ideology, but by Chinese nationalism that has been in the making since the late nineteenth century, when Taiwan was ceded to Japan after the Sino-Japanese War (1894-95). The PLA needs to develop its own theory and tactics of modern warfare to deal with a possible crisis. The new theory and tactics should be based upon a new international environment and China's needs for its development.

Thus, perhaps the most important among them, and the most effective for the longterm, is the significant improvement in China's international standing related primarily, but not only to a reduction in global and regional threats of conflict. The Chinese strategic analysts and military experts have an optimistic view of the current national security and opportunity in the near future. While factors of insecurity and instability remain, they enjoy a favorable surrounding security environment, something seldom seen since the founding of the PRC. It seems possible for the PLA to avoid a major war for a fairly long period of time. The relaxation is still the general trend in the international security situation. In general, the way things are going, there are more opportunities and challenges, and more hopes and difficulties ahead for the PLA.

\section{References}

Babbin, J. and Timperlake, E. Showdown: Why China Wants War with the United States. Washington, D.C.: Regency, 2006.

Baker, P. “Obama Calls for Military Dialogue with China.” New York Times, March 12, 2009.

Peace and Conflict Studies $•$ Volume 16, Number 2 
Bernstein R. and Munro, R. H. The Coming Conflict with China. New York: Knopt, 1997. Chang, G. The Coming Collapse of China. New York: Random House, 2001.

Ge, C. (ed.). Laozhanshi yishi (Personal Stories of the Veterans). Beijing: Zhongguo duiwai fanyi chubanshe (China International Translation Publishing), 2000.

Goldstein, L. "Cold War at Sea”. Joint Forces Quarterly, April 2008, $<$ http://www.armedforcesjournal.com/2008/04/3373649> (24 September 2008).

Getz, B. The China Threat: How the People's Republic Targets America. Washington, D.C.: Regency, 2000.

Getz, B. "Inside the Ring”. Washington Times, July 10, 2008, $<$ http://www.washingtontimes.com/news/2008/jul/10/inside-the-ring-83281533> (14 August 2008).

Graff, D. A. and Higham, R. (eds.). A Military History of China. Boulder, Col.: Westview, 2002.

Harding, H. “Chinese Nuclear Submarine Base”, The Daily Telegraph, May 6 2008, <http://www.telegraph.co.uk/news/majornews?1917167?Chinese-build-secretnuclearsubarine-base-html> (15 June 2008).

He, M. Jianzheng: Chaoxian zhanzheng zhafu qianfan Jieshi daibiao de riji (Witness: Diary of a Representative for the Explanatory Task to Repatriate POWs). Beijing: Zhongguo wenshi chubanshe (China Literature and History Publishing), 2001.

Hong, G. Z. “"The China Uniqueness'-Puzzles and Interpretations of China's Development.” American Review of China Studies, 2005, 6 (1), 1-26.

$\mathrm{Hu}, \mathrm{J}$. "Hu Jintao Called the Trio Taikonauts in the Space."

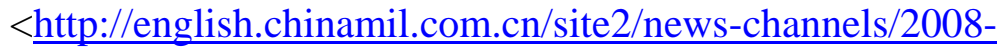
09/28/content_1494048.htm> (2 October 2008).

$\mathrm{Hu}, \mathrm{J}$. "Hu Jintao's Remarks at the $14^{\text {th }}$ Congress of the Chinese Academy of Sciences (CAS).” < http://english.chinamil.com.cn/site2/news-channels/200806/24/content_1329137.htm> (3 October 2008).

$\mathrm{Hu}$, J. "Hu Jintao’s Remarks during his visit to the Research Center.” PLA Daily, March 22, 2008, 1-2, <http://english.chinamil.com.cn/site2/news-channels/200803/22/content_1172650.htm> (20 August 2008).

$\mathrm{Hu}$, J. "Hu Jintao's Keynote Speech at the CCP $17^{\text {th }}$ National Congress, October 2007." $<$ http://english.peopledaily.com.cn/90002/92169/92187/6283161.htm> (8 September 2008).

Hu, J. “Hu Jintao’s Speech at the 'Four Headquarters' (sizongbu) Meeting in August 2000.” Taiyangbao (Sun Daily), September 5, 2000, 1-3.

$\mathrm{Hu}, \mathrm{Q}$. Chaoxian zhanzheng zhong de nuren (Women in the Korean War). Jinan, Shandong: Huanghe chubanshe (Yellow River Press), 1992.

Information Bureau, State Council of the PRC. White Papers of China's National Defense in 2004. Beijing: Foreign Languages Press, 2005.

Information Bureau, State Council of the PRC. White Papers of China's National Defense in 2006, < http://www.chinadaily.com.cn/china/2006-12/29/content_771191.htm>

(19 September 2008).

Information Bureau, State Council of the PRC. White Papers of China's National Defense in 2008, <http://English.people.com.cn/90001/90776/90785/6578688.html> 
(28 January 2009).

Joffe, E. The Chinese Army after Mao. Cambridge, Ma: Harvard University Press, 1987.

Karmel, S. China and the People's Liberation Army. New York: St. Martin's Press, 2000.

Kay, D. J. "Engaging the 'New China'.” National Security Watch, September 2, 2008, 126.

Kristof, N. and Wudunn, S. China Wakes: The Struggle for the Soul of a Rising Power. New York: Vintage Books, 1994.

Li, C. China's Leaders; The New Generation. Lanham, Md.: Rowman and Littlefield Publishers, 2001.

Li, X. A History of the Modern Chinese Army. Lexington, Ky.: University Press of Kentucky, 2007.

Lilley, J. R. and Shambaugh, D. (eds.). China's Military Faces the Future. New York: M. E. Sharpe, 1999.

Minnick, W. “U.S. Questions China’s Budget Transparency.” Defense News, September 22, 2008, < http://wendellminnick.blogspot.com> (3 October 2008).

PLA Daily, <http://english.chinamil.com.cn/site2/news-channels/200806/06/content_1302900.htm> (14 October 2008).

Pollack, J. D. “The Transformation of the Asian Security Order; Assessing China’s Impact.” In Shambaugh (ed.). Power Shift; China and Asia's New Dynamics. Berkeley, Ca: University of California Press, 2005.

Ryan, M. A., Finkelstein, D. M., and McDevitt, M. A. (eds.). Chinese Warfighting; The PLA Experience since 1949. New York: M. E. Sharpe, 2003.

Scobell, A. China's Use of Military Force; Beyond the Great Wall and the Long March. New York: Cambridge University Press, 2003.

Shambaugh D. (ed.). Power Shift; China and Asia’s New Dynamics. Berkeley, Ca: University of California Press, 2005.

Shambaugh, D. Modernizing China's Military: Progress, Problems, and Prospects. Berkeley, Ca: University of California Press, 2002.

Tan, Z. Zhongguo renmin zhiyuanjun renwulu (Veterans Profile of the Chinese People's Volunteer Force). Beijing: Zhonggong dangshi chubanshe (CCP Party History Publishing), 1992.

U.S. Department of Defense. Annual Report to Congress: Military Power of the People's Republic of China, 2008,

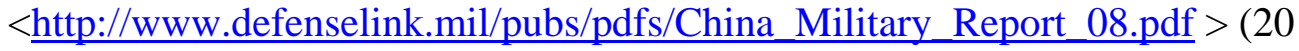
November 2008).

van de Ven, H. (ed.). Warfare in Chinese History. Leiden: E. J. Brill, 2000.

Wang, Z. (2005). "US Congress Calls for Sacking of Chinese General.” The Epoch Times, 2005, <http://www.theepochtimes.com/news/5-7-25/30545.html> (10 July 2008).

You, J. The Armed Forces of China. New York: I. B. Tauris, 1999.

Yu, S. (ed.). Lun lianhe zhanyi (On Joint Warfare). Beijing: Guofang daxue chubanshe (National Defense University Press), 1998. 
Xiong, G. “On Revolution in Military Affairs.” Xiong, G. (ed.). Guoji zhanlue yu xinjunshi biange (International Strategy and Revolution in Military Affairs). Beijing: Qinghua daxue chubanshe (Qinghua University Press), 2003.

Xiong, G. "On Revolution in Military Affairs". a presentation at the "Chinese Scientists' Forum on Humanities” on April 16, 2003. Guoji zhanlue yanjiu (International Strategic Studies) 3 (Beijing, July 2003), 1-21. 